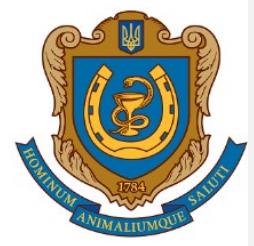

Ukrainian Journal of

Veterinary and Agricultural Sciences

http://ujvas.com.ua

Stepan Gzhytskyi National University of Veterinary Medicine and Biotechnologies Lviv

original article $\mid$ UDC 619:619.661 $\mid$ doi: 10.32718/ujvas3-1.08

Volume 3

Number 1

\title{
Influence of milk thistle, methifene and sylimevit on the morphological parameters of laying hens in experimental chronic cadmium toxicosis
}

\author{
A. Y. Ostapyuk, B. V. Gutyj \\ Stepan Gzhytskyi National University of Veterinary Medicine and Biotechnologies, Pekarska Str., 50, Lviv, 79010, Ukraine
}

\begin{tabular}{l} 
Article info \\
Received 04.02.2020 \\
Received in revised form \\
05.03.2020 \\
Accepted 06.03.2020 \\
\hline Correspondence author \\
Bogdan Gutyj \\
Tel.: +38-068-136-20-54 \\
E-mail: bvh@ukr.net \\
\hline
\end{tabular}

2020 Ostapyuk A. Y. et al. This is an open-access article distributed under the terms of the Creative Commons Attribution License, which permits unrestricted use, distribution, and reproduction in any medium, provided the original author and source are credited.

\section{$(\mathrm{cc}) \mathrm{Br}$}

\section{Contents}

1. Introduction

2. Materials and methods ........ 43

3. Results and discussion ....... 43

4. Conclusions ................ 44

References

\begin{abstract}
One of the most pressing problems of modern science is the systematic study of natural processes, forecasting and complex assessment of changes in the environment under the influence of anthropogenic load. Blood composition is a relatively constant indicator, which is at the same time one of the labile systems of laying hens. Physiological processes that occur in the body, largely affect the quality of blood. Hematological studies make it possible to study in more detail the effect of cadmium on the body of chickens, on the basis of which a more specific development of the scheme of treatment and prevention of cadmium toxicosis in poultry is possible. The aim of this study was to investigate the effect of milk thistle, methifene and silymevitis on the morphological indices of laying hens in the development of chronic cadmium toxicosis. 32 laying hens, 78 weeks of age, were selected for the study. Four experimental groups were formed: control and three experimental. The control group (C) chickens and the three experimental groups were cadmium sulfate $4 \mathrm{mg} / \mathrm{kg}$ body weight in water. The chickens of the experimental group E1 with feed were fed the fruits of milk thistle spotted at a dose of $2.0 \mathrm{~g} / \mathrm{kg}$ of feed once a day for 30 days. The chickens of the E2 experimental group were fed methifene at a dose of $0.28 \mathrm{~g} / \mathrm{kg}$ of feed once a day for 30 days with feed. The chickens of the E3 experimental group were fed a sylimevit at a dose of $0.36 \mathrm{~g} / \mathrm{kg}$ of feed once a day for 30 days. Drinking cadmium sulphate to laying hens at a dose of $4 \mathrm{mg} / \mathrm{kg}$ body weight contributed to a decrease in red blood cell count, hemoglobin level and an increase in leukocyte counts. With cadmium load of laying hens, milk thistle, methifene and sylimevit have a positive effect on the morphological parameters of the blood. In chronic cadmium toxicosis in laying hens, the best normalizing effect on the morphological parameters of the blood of experimental chickens is sylimevit, compared with methifene and milk thistle.
\end{abstract}

Key words: toxicology, cadmium, poultry, blood, sylimevit, methifene, milk thistle.

Citation:

Ostapyuk, A. Y., \& Gutyj, B. V. (2020). Influence of milk thistle, methifene and sylimevit on the morphological parameters of laying hens in experimental chronic cadmium toxicosis. Ukrainian Journal of Veterinary and Agricultural Sciences, 3(1), 42-46.

\section{Introduction}

The problem of environmental pollution by Cadmium, which is one of the consequences of the intensification of industrial and agricultural production, has become particularly relevant today (Uetani et al., 2005; Nazaruk et al., 2015; Sachko et al., 2016). Over the last decades, the growth of the content of this metal in soils of Ukraine and other countries has been accompanied by the accumulation of $\mathrm{Cd}^{2+}$ in agricultural products and feed, increasing the threat to human and animal health. (Hutyi, 2013; Gutyj et al., 2015; Hradovych et al., 2016; Grushanska, 2017).

The toxic effect of cadmium is manifested in a number of tissues and organs (kidneys, liver, lungs, glands), systems (excretory, cardiovascular, hematopoietic) (Fregoneze et al., 1997; Rodríguez et al., 2001; Lu et al., 2005; Liu et al., 2008; Al-Azemi et al., 2010). Cadmium is characterized by a long half-life in humans and animals, interaction with divalent metals, both at the level of absorption and at the level of metabolism in tissues and organs (Antonio et al., 1998; Pavan Kumar \& Prasad, 2004; El-Shahat et al., 2009).

Cadmium and its compounds are immunotoxicants that cause impaired functioning of the body's immune system, reduce resistance to infections, contribute to the formation of allergic, autoimmune and cancer pathologies (Ali et al., 1986; Salvatori et al., 2004; El-Refaiy \& Eissa, 2012; Peng et al., 2015; Gutyj, 2015).

In this regard, the particular effects of Cadmium on human and animal organisms have been the subject of detailed study, especially over the last decade.

The aim of this study was to investigate the effect of milk thistle, methifene and silymevit on the morphological indices of laying hens in the development of chronic cadmium toxicosis. 


\section{Materials and methods}

32 laying hens, 78 weeks of age, were selected for the study. Four experimental groups were formed: control and three experimental. The control group (C) chickens and the three experimental groups were cadmium sulfate $4 \mathrm{mg} / \mathrm{kg}$ body weight in water. The chickens of the experimental group E1 with feed were fed the fruits of milk thistle spotted at a dose of $2.0 \mathrm{~g} / \mathrm{kg}$ of feed once a day for 30 days. The chickens of the E2 experimental group were fed methifene at a dose of $0.28 \mathrm{~g} / \mathrm{kg}$ of feed once a day for 30 days with feed. The chickens of the E3 experimental group were fed a sylimevit at a dose of $0.36 \mathrm{~g} / \mathrm{kg}$ of feed once a day for 30 days.

The conditions of keeping the chickens and the indoor climate in all groups were similar. During the experiment, the amount of feed and water consumed was counted.

All experimental interventions and animal slaughter were carried out in accordance with the requirements of the "European Convention for the Protection of Vertebrate Animals Used for Experimental and Scientific Purposes" (Strasbourg, 1985) and the decisions of the First National Congress on Bioethics (Kyiv, 2001).

Blood from laying hens was collected from the coronary vein during periods: prior to administration of cadmium preparations and sulfate, on the first, seventh, fourteenth, twenty-first and thirtieth days of the experiment.

The amount of red blood cells was determined in heparin-stabilized blood - photonephelometrically according to the method of Ye. S. Havrylets et al. (1966); leukocytes using the Goryaev grid in the counting chamber (V. E. Chumachenko, 1991); hemoglobin concentration hemoglobincyanide method according to G. V. Dervis and A. G. Vorobyov (1959) (Vlizlo, 2012).

In the experiments we used the following drugs:

Cadmium sulfate is Cadmium sulfate, an inorganic compound of the chemical formula CdSO4. Cadmium sulfate is well soluble in water, so it is well absorbed in the digestive canal, into the bloodstream and is known for its toxic effects on living organisms.

Milk thistle (MT) - Silybum marianum is a family of flowering plants, in the wild, grows on wastelands, along roads, in abandoned fields, and is cultivated in medicinal gardens. For the treatment used fruits thistle spotted. They contain protein $17-18 \%$, fats $10-11 \%$, flavolignans $2-3 \%$, essential oil $0.08 \%$, vitamins $\mathrm{A}, \mathrm{E}, \mathrm{K}$, biogenic amines, quartzetin.

Methifen (M) is a white crystalline powder, sweet in taste, with a smell of sulfur. It dissolves poorly in cold water, better in hot water $(1: 20)$. Thermostable. The drug contains fenarone and methionine.

Sylimevit (S) is a feed additive that includes the fruits of milk thistle, selenium, methifene, vitamins A, E and C.

Analysis of the research results was performed using the Statistica 6.0 software package. The likelihood of differences was evaluated by Student's t-test. The mean values were considered statistically significant at $*-\mathrm{P}<0.05$, $* *-\mathrm{P}<0.01, * * *-\mathrm{P}<0.001$ (ANOVA).

\section{Results and discussion}

Blood composition is a relatively constant indicator, which is at the same time one of the labile systems of laying hens. Physiological processes that occur in the body, largely affect the quality of blood (Gutyj et al., 2015; Gutyj et al., 2016). Hematological studies make it possible to study in more detail the effect of cadmium on the body of chickens, on the basis of which a more specific development of the scheme of treatment and prevention of cadmium toxicosis in poultry is possible.

It was established that the number of erythrocytes in the diseased poultry decreased to $2.36 \pm 0.14 \mathrm{~T} / \mathrm{l}$ during the experiment (Table 1). With the use of cadmium loading drugs in experimental groups, the number of red blood cells in their blood gradually increased. When setting milk thistle to chickens in the experimental group E1, we found an increase in the number of red blood cells in their blood for the 14 th day of the experiment by $5 \%$ relative to the values of the control group of chickens who were not treated. A similar difference in the number of erythrocytes is observed in the blood of experimental groups of chickens fed with methifene and sylimevit, where in the experimental group E2 the number of erythrocytes increased by $6 \%$ for the 14 th day of the experiment and by $8 \%$ in the experimental group E3. On the $21 \mathrm{st}$ day of the experiment, we observe a probable difference in the number of red blood cells in all experimental groups, where, respectively, in the experimental group E1 the number of red blood cells was $2.87 \pm 0.16 \mathrm{~T} / 1$, in the experimental group $\mathrm{E} 2-2.98 \pm$ $0.12 \mathrm{~T} / \mathrm{l}$, in the experimental group $\mathrm{E} 3-3.17 \pm 0,16 \mathrm{~T} / \mathrm{l}$.

\section{Table 1}

The number of erythrocytes in the blood of laying hens after administration of milk thistle, methifene and silymevit in chronic cadmium toxicosis; $(\mathrm{M} \pm \mathrm{m}, \mathrm{n}=8)$

\begin{tabular}{ccccc}
\hline & \multicolumn{4}{c}{ Erythrocytes (T/1) } \\
\cline { 2 - 5 } Time of blood research (day) & \multicolumn{4}{c}{ Hen groups } \\
\cline { 2 - 5 } & Control (cadmium) & $\begin{array}{c}\text { Experimental 1 } \\
\text { (cadmium + MT) }\end{array}$ & $\begin{array}{c}\text { Experimental 2 } \\
\text { (cadmium + M) }\end{array}$ & $\begin{array}{c}\text { Experimental 3 } \\
\text { (cadmium + S) }\end{array}$ \\
\hline On the beginning of the research & $3.15 \pm 0.10$ & $3.19 \pm 0.09$ & $3.12 \pm 0.11$ & $3.20 \pm 0.12$ \\
First day & $3.11 \pm 0.13$ & $3.18 \pm 0.10$ & $3.14 \pm 0.10$ & $3.19 \pm 0.10$ \\
7 day & $3.07 \pm 0.15$ & $3.08 \pm 0.15$ & $3.10 \pm 0.15$ & $3.14 \pm 0.15$ \\
14 day & $2.87 \pm 0.14$ & $3.02 \pm 0.14$ & $3.05 \pm 0.16$ & $3.11 \pm 0.14^{*}$ \\
21 day & $2.36 \pm 0.14$ & $2.87 \pm 0.16^{*}$ & $2.98 \pm 0.12^{*}$ & $3.17 \pm 0.16^{* *}$ \\
30 day & $2.49 \pm 0.09$ & $3.15 \pm 0.14^{* *}$ & $3.17 \pm 0.15^{* *}$ & $3.28 \pm 0.14^{* * *}$ \\
\hline
\end{tabular}

Cadmium load of laying hens at $4 \mathrm{mg} / \mathrm{kg}$ body weight was accompanied by a decrease in hemoglobin concentration in their blood. The hemoglobin concentration in the blood of ill poultry ranged from $97.54 \pm 0.65-72.17 \pm$ $0.73 \mathrm{~g} / \mathrm{l}$. The lowest hemoglobin concentration was at 21 days of the experiment (Table 2). The use of experimental 
drugs helped to normalize the concentration of hemoglobin in the blood of laying hens throughout the experience. In poultry fed with milk thistle, the hemoglobin concentration increased relative to the control group of animals at the 7th day of the experiment by $11.2 \%$, at the 14 th day of the experiment - by $17.7 \%$, by the 21 st day of the experiment by $34.6 \%$ and by 30 days of experience, respectively, by $17 \%$.

Feeding with methifene feed also increased the hemoglobin concentration in the blood of the experimental group of chickens under cadmium load. It was found that on the 7th day of the experiment the hemoglobin concentration in the blood of chickens of the experimental group E2 was $97.36 \pm 1.15 \mathrm{~g} / \mathrm{l}$, whereas in the control group this indicator was significantly lower and accordingly was $87.32 \pm 1.10 \mathrm{~g} / \mathrm{l}$. On the 14 th day of the experiment we notice a slight decrease in hemoglobin level, however, on the 21st and 30th day of the experiment, the hemoglobin concentration fluctuated within physiological values.

\section{Table 2}

Concentration of hemoglobin in the blood of laying hens after administration of milk thistle, methifene and silymevit in chronic cadmium toxicosis; $(\mathrm{M} \pm \mathrm{m}, \mathrm{n}=8)$

\begin{tabular}{ccccc}
\hline & \multicolumn{4}{c}{ Hemoglobin g/l } \\
\cline { 2 - 5 } Time of blood research (day) & \multicolumn{4}{c}{ Hen groups } \\
\cline { 2 - 5 } & Control (cadmium) & $\begin{array}{c}\text { Experimental 1 } \\
\text { (cadmium }+\mathrm{MT})\end{array}$ & $\begin{array}{c}\text { Experimental 2 } \\
\text { (cadmium }+\mathrm{M})\end{array}$ & $\begin{array}{c}\text { Experimental 3 } \\
\text { (cadmium }+\mathrm{S})\end{array}$ \\
\hline On the beginning of the research & $98.58 \pm 0.73$ & $99.10 \pm 0.66$ & $98.75 \pm 0.70$ & $98.58 \pm 0.71$ \\
First day & $97.54 \pm 0.65$ & $99.15 \pm 0.85$ & $98.95 \pm 1.13$ & $98.70 \pm 0.99$ \\
7 day & $87.32 \pm 1.10$ & $97.14 \pm 0.97 * * *$ & $97.36 \pm 1.15^{* * *}$ & $98.87 \pm 1.22^{* * *}$ \\
14 day & $81.22 \pm 1.20$ & $95.56 \pm 1.03^{* * *}$ & $96.04 \pm 0.95^{* * *}$ & $99.45 \pm 0.99^{* * *}$ \\
21 day & $72.17 \pm 0.73$ & $97.12 \pm 1.21^{* * *}$ & $96.23 \pm 1.18^{* * *}$ & $99.78 \pm 1.35^{* * *}$ \\
30 day & $83.56 \pm 0.93$ & $97.81 \pm 1.14^{* * *}$ & $97.45 \pm 0.99^{* * *}$ & $100.12 \pm 1.21^{* * *}$ \\
\hline
\end{tabular}

When feding with the feed of sylimevit in the blood of laying hens under cadmium loading, the concentration of hemoglobin fluctuated within physiological values.

Increased hemoglobin concentration is associated with an increase in the number of erythrocytes in the blood of chickens fed with experimental drugs.

Experiments on laying hens have found that the cadmium load increases the number of leukocytes in their blood, which is associated with the toxic impact of this toxicant on the body of chickens and the development of inflammatory processes in their body. The use of milk thistle, methifene and silimevit contributes to the increased resistance of the body to the effects of toxic substances, which is manifested by the decrease in the number of leukocytes in the blood of laying hens in chronic cadmium toxicosis (Table 3 ).

Table 3

The number of leukocytes in the blood of laying hens after administration of milk thistle, methifene and sylimevit in chronic cadmium toxicosis; $(\mathrm{M} \pm \mathrm{m}, \mathrm{n}=8)$

\begin{tabular}{ccccc}
\hline & \multicolumn{4}{c}{ Leukocytes (G/1) } \\
\cline { 2 - 5 } Time of blood research (day) & \multicolumn{4}{c}{ Hen group } \\
\cline { 2 - 5 } & Control (cadmium) & $\begin{array}{c}\text { Experimental 1 } \\
\text { (cadmium }+ \text { MT) }\end{array}$ & $\begin{array}{c}\text { Experimental 2 } \\
\text { (cadmium }+ \text { M) }\end{array}$ & $\begin{array}{c}\text { Experimental 3 } \\
\text { (cadmium }+ \text { S) }\end{array}$ \\
\hline On the beginning of the research & $31.8 \pm 0.70$ & $31.7 \pm 0.75$ & $31.5 \pm 0.58$ & $31.3 \pm 0.62$ \\
First day & $32.4 \pm 0.55$ & $32.0 \pm 0.87$ & $31.8 \pm 0.95$ & $31.5 \pm 1.10$ \\
7 day & $34.1 \pm 0.70$ & $32.8 \pm 0.90$ & $33.0 \pm 1.20$ & $32.0 \pm 0.99$ \\
14 day & $34.7 \pm 0.65$ & $32.6 \pm 1.15^{*}$ & $32.7 \pm 1.10^{*}$ & $32.3 \pm 1.06^{*}$ \\
21 day & $35.8 \pm 0.66$ & $32.9 \pm 0.59^{* *}$ & $32.5 \pm 1.04^{* *}$ & $31.7 \pm 1.11^{* *}$ \\
30 day & $34.1 \pm 0.70$ & $32.3 \pm 1.10$ & $32.3 \pm 1.25$ & $31.5 \pm 0.95^{*}$ \\
\hline
\end{tabular}

These drugs had a positive effect on the level of leukocytes in the blood of the experimental bird, so in group E1 the number of leukocytes for the 7th day of the experiment was $32.8 \pm 0.90 \mathrm{G} / 1$, and in the experimental group of animals R2 the number of leukocytes was respectively $33.0 \pm$ $1.20 \mathrm{G} / 1$. At 14 and 21 days of the experiment the number of leukocytes continued to decrease and relative to the control group it was lower in the group E1 by 6 and $8 \%$, and in the experimental group E2 by 5.8 and $9 \%$ respectively.

When feeding sylimevit to chickens for 30 days, the normalization of leukocyte counts was established throughout the experiment. Thus, on the 7 th and 14th day of the experiment, the number of leukocytes decreased by 6 and
$7 \%$ compared with the control group of chickens. More likely changes in the number of leukocytes were observed at 21 and 30 days of the experiment, where compared with the control group of chickens, they decreased by 12 and $8 \%$.

\section{Conclusions}

Drinking cadmium sulphate to laying hens at a dose of $4 \mathrm{mg} / \mathrm{kg}$ body weight contributed to a decrease in red blood cell count, hemoglobin level and an increase in leukocyte counts. 
With cadmium load of laying hens, milk thistle, methifene and sylimevit have a positive effect on the morphological parameters of the blood.

In chronic cadmium toxicosis in laying hens, the best normalizing effect on the morphological parameters of the blood of experimental chickens is sylimevit, compared with methifene and milk thistle.

\section{References}

Al-Azemi, M., Omu, F. E., Kehinde, E. O., Anim, J. T., Oriowo, M. A., \& Omu, A. E. (2010). Lithium protects against toxic effects of cadmium in the rat testes. J. Assist. Reprod. Genet, 27(8), 469-476. doi: 10.1007/s10815-010-9426-3.

Ali, M. M., Murthy, R. C., \& Chandra, S. V. (1986). Developmental and longterm neurobehavioral toxicity of lowlevel in utero Cd exposure in rats. Neurobehavioral Toxicology and Teratology, 8(5), 463-468. https://www.ncbi.nlm.nih.gov/ pubmed/3785508.

Antonio, M. T., Benito, M. J., Leret, M. L., \& Corpas, I. (1998). Gestation administration of cadmium alters the neurotransmitter levels in newborn rat brains. $J$ Appl Toxicol., 18(2), 83-88. https://www.ncbi.nlm.nih.gov/pubmed/9570689.

El-Refaiy, A. I., \& Eissa, F. I. (2012). Protective effects of ascorbic acid and zinc against cadmium-induced histopathological, histochemical and cytogenetic changes in rats. Comunicata Scientiae, 3(3), 162-180. https://www.comunicatascientiae. com.br/comunicata/article/view/186/136

El-Shahat, A. E., Gabr, A., Meki, A. R., \& Mehana, E. S. (2009). Altered testicular morphology and oxidative stress induced by cadmium in experimental rats and protective effect of simultaneous green tea extract. Int. J. Morphol., 27(3), 757764. doi: $10.4067 /$ S0717-95022009000300020.

Fregoneze, J. B., Marinho, C. A., Soares, T., Castro, L., Sarmento, C., Cunha, M., Gonzalez, V., Oliveira, P., Nascimento, T., Luz, C.P., Santana, Jr. P., De-Oliveira, I.R., \& e-Castro-e-Silva, E. (1997). Lead $(\mathrm{Pb} 2+)$ and cadmium $(\mathrm{Cd} 2+)$ inhibit the dipsogenic action of central beta-adrenergic stimulation by isoproterenol. Brazilian Journal of Medical and Biological Research, 30(3), 419-423. doi: 10.1590/S0100-879X1997000300018.

Grushanska, N. (2017). The content of heavy metals in the cow hair of the northern-eastern biogeochemical zone. Scientific Messenger of LNU of Veterinary Medicine and Biotechnologies, 19(73), 154-158. doi: 10.15421/nvlvet7332.

Gutyj, B. V. (2015). The activity of antioxidant protecting of the bulls for acute cadmium toxicosis. Scientific Messenger of LNU of Veterinary Medicine and Biotechnologies, 17(1), 3136. Retrieved from https://nvlvet.com.ua/index.php/journal/ article/view/214.

Gutyj, B. V., Binkevych, V., \& Binkevych, O. (2016). Hematological changes of rats after cadmium toxicosis. Scientific Messenger of LNU of Veterinary Medicine and Biotechnologies, 18(1), 165-167. Retrieved from https://nvlvet.com.ua/index.php/journal/article/view/110.

Gutyj, B. V., Gufrij, D., Binkevych, V., Binkevych, O., Kurlyak, I., \& Sobolta, A. (2015). Influence of Mevesel \& E-selenium on level of intermediate and final products of lipid peroxidation in bulls' blood after cadmium loading. Scientific Messenger of LNU of Veterinary Medicine and Biotechnologies, 17(1), 190194. Retrieved from https://nvlvet.com.ua/index.php/journal/ article/view/292.

Gutyj, B., Hufriy, D., Binkevych, V., Vischur, V., Binkevych, O., \& Kurlyak, I. (2015). The changes of biochemical and morphological indices of rats' blood under chronic cadmium toxicosis. Scientific Messenger of LNU of Veterinary Medicine and Biotechnologies, 17(3), 120-123. Retrieved from https://nvlvet.com.ua/index.php/journal/article/view/531.

Hradovych, N., Paranyak, R., \& Zabytivskyi, Y. (2016). Influence of zeolites on lead and cadmium content in separate links of trophic chain in hydroecosystems. Scientific Messenger of LNU of Veterinary Medicine and Biotechnologies, 18, 2(67), 61-65. doi: $10.15421 /$ nvlvet6714.

Hutyi, B. V. (2013). Riven pokaznykiv nefermentnoi systemy antyoksydantnoho zakhystu orhanizmu bychkiv za umov kadmiievoho navantazhennia. Naukovyi visnyk Lvivskoho natsionalnoho universytetu veterynarnoi medytsyny ta biotekhnolohii im. Gzhytskoho, 15, 1(4), 40-45. Rezhym dostupu: http://nbuv.gov.ua/UJRN/nvlnu_2013_15_1(4)_10 (in Ukrainian),

Hutyi, B. V. (2013). Vmist vitaminiv A i E u krovi bychkiv za umov kadmiievoi intoksykatsii. Visnyk Sumskoho natsionalnoho ahrarnoho universytetu. Seriia: Veterynarna medytsyna, 2, 31-33. Rezhym dostupu: http://nbuv.gov.ua/ UJRN/Vsna_vet_2013_2_10 (in Ukrainian).

Hutyi, B. V. (2013). Vplyv E-selenu na aktyvnist hlutationovoi systemy antyoksydantnoho zakhystu orhanizmu buhaitsiv pry kadmiievomu navantazhenni. Visnyk Sumskoho natsionalnoho ahrarnoho universytetu. Seriia: Veterynarna medytsyna, 9, 7073. Rezhym dostupu: http://nbuv.gov.ua/UJRN/ Vsna_vet_2013_9_22 (in Ukrainian).

Hutyi, B. V. (2013). Vplyv E-selenu na vmist vitaminiv A i E u krovi bychkiv za umov kadmiievoi intoksykatsii. Naukovyi visnyk Lvivskoho natsionalnoho universytetu veterynarnoi medytsyny ta biotekhnolohii im. Gzhytskoho, 15, 3(3), 311-314. Rezhym dostupu: http://nbuv.gov.ua/UJRN/nvlnu_2013_15_3(3)__55 (in Ukrainian).

Hutyi, B. V. (2013). Vplyv khlorydu kadmiiu u riznykh dozakh na aktyvnist aminotransferaz syrovatky krovi buhaitsiv. Naukovyi visnyk Lvivskoho natsionalnoho universytetu veterynarnoi medytsyny ta biotekhnolohii im. Gzhytskoho, 15, 1(1), 49-52. Rezhym dostupu: http://nbuv.gov.ua/UJRN/ nvlnu_2013_15_1(1)_11 (in Ukrainian).

Hutyi, B. V. (2013). Vplyv khlorydu kadmiiu u toksychnykh dozakh na hlutationovu systemu antyoksydantnoho zakhystu orhanizmu bychkiv. Veterynarna biotekhnolohiia, 22, 112-116. Rezhym dostupu: http://nbuv.gov.ua/UJRN/vbtb 20132223 (in Ukrainian).

Hutyi, B. V. (2013). Vplyv Meveselu na pokaznyky neenzymnoi systemy antyoksydantnoho zakhystu orhanizmu buhaitsiv za umov kadmiievoho navantazhennia. Biolohiia tvaryn, 15(3), 16-21. Rezhym dostupu: http://nbuv.gov.ua/UJRN/ bitv_2013_15_3_4 (in Ukrainian).

Hutyi, B. V. (2013). Vplyv meveselu na vmist vitaminiv A i E u krovi bychkiv za umov kadmiievoi intoksykatsii. Naukovyi visnyk Lvivskoho natsionalnoho universytetu veterynarnoi medytsyny ta biotekhnolohii im. Gzhytskoho, 15, 3(1), 78-82. Rezhym dostupu: http://nbuv.gov.ua/UJRN/nvlnu_2013_15_3(1)_18 (in Ukrainian).

Hutyi, B. V. (2013). Vplyv meveselu ta E-selenu na riven pokaznykiv ne fermentnoi systemy antyoksydantnoho zakhystu orhanizmu buhaitsiv pry kadmiievomu navantazhenni. Veterynarna medytsyna, 97, 419-421. Rezhym dostupu: http://nbuv.gov.ua/UJRN/vetmed 2013 97172 (in Ukrainian).

Khariv, M., Gutyj, B., Butsyak, V., \& Khariv, I. (2016). Hematological indices of rat organisms under conditions of oxidative stress and liposomal preparation action. Biological Bulletin of Bogdan Chmelnitskiy Melitopol State Pedagogical University, 6(1), 276-289. doi: http://dx.doi.org/10.15421/201615.

Liu, J., Qian, S. Y., Guo, Q., Jiang, J., Waalkes, M. P., Mason, R. P., \& Kadiiska, M. B. (2008). Cadmium generates reactive oxygen- and carbon-centered radicalspecies in rats: Insights from in vivo spin-trappingstudies. Free Radic Biol Med., 45(4), 475-481. doi: 10.1016/j.freeradbiomed.2008.04.041.

Lu, J., Jin, T., Nordberg, G., \& Nordberg, M. (2005). Metallothionein gene expression in peripheral lymphocytes and renal dysfunction in a population environmentally exposed to cadmium. Toxicol Appl Pharmacol, 206(2), 150-156. doi: 10.1016/j.taap.2004.12.015.

Nazaruk, N., Gutyj, B., \& Hufriy, D. (2015). Influence of metifen and vitamix se on the activity of aminotransferases of bulls blood serum at cadmium nitrate loading. Scientific Messenger 
of LNU of Veterinary Medicine and Biotechnologies, 17(1), 121-126. Retrieved from https://nvlvet.com.ua/index.php/ journal/article/view/231.

Pavan Kumar, G., \& Prasad, M. N. V. (2004). Cadmium-Inducible Proteins in Ceratophyllum demersum L. (a Fresh Water Macrophyte): Toxicity Bioassays and Relevance to Cadmium Detoxification. Bulletin of Environmental Contamination and Toxicology, 73(1), 174-181. doi: 10.1007/s00128-004-0410-4.

Peng, L., Wang, X., Huo, X., Xu, X., Lin, K., Zhang, J., Huang, Y., $\& \mathrm{Wu}, \mathrm{K}$. (2015). Blood cadmium burden and the risk of nasopharyngeal carcinoma: a case-control study in Chinese Chaoshan population. Environmental Science and Pollution Research, 22(16), 12323-12331. doi: 10.1007/s11356-015-4533-4.

Rodríguez, E. M., Bigi, R., Medesani, D. A., Stella, V. S., Greco, L. S. L., Moreno, P. A. R., Monserrat, J. M., Pellerano, G. N., \& Ansaldo, M. (2001). Acute and chronic effects of cadmium on blood homeostasis of an estuarine crab, Chasmagnathus granulata, and the modifying effect of salinity. Brazilian Journal of Medical and Biological Research, 34(4), 509-518. https://www.ncbi.nlm.nih.gov/pubmed/11285463.
Sachko, R. G., Lesyk, Ja. V., Luchka, I. V., \& Nevostruyeva, I. V. (2016). Contents of heavy metals in food, organism and animal products in the Zacarpathian biogeochemical province. Scientific Messenger LNUVMBT named after S.Z. Gzhytskyj, 18, 3(71), 87-90. doi: 10.15421/nvlvet7120.

Salvatori, F., Talassi, CB, Salzgeber, S.A., Sipinosa, H.S., \& Bernardi, M.M. (2004). Embryotoxic and long-term effects of cadmium exposure during embryogenesis in rats. Neurotoxicology and Teratology, 26(5), 673-680. doi: 10.1016/j.ntt.2004.05.001.

Uetani, M., Kobayashi, E., Suwazono, Y., Okubo, Y., Honda, R., Kido, T., \& Nogawa, K. (2005). Selenium, Cadmium, Zinc, Copper, and Iron Concentrations in Heart and Aorta of Patients Exposed to Environmental Cadmium. Bulletin of Environmental Contamination and Toxicology, 75(2), 246-250. doi: 10.1007/s00128-005-0744-6.

Vlizlo, V. V. (2012). Laboratorni metody doslidzhen u biolohiyi, tvarynnytstvi ta veterynarniy medytsyni [Laboratory methods of investigation in biology, stock-breeding and veterinary]. Spolom, Lviv (in Ukrainian). 